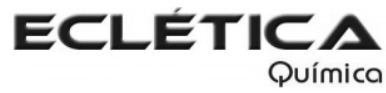

www.scielo.br/eq

www.ecletica.iq.unesp.br

Volume 32, número 4, 2007

\title{
Methylene blue adsorption onto modified lignin from sugar cane bagasse
}

\author{
N. Consolin Filho ${ }^{a}$, E. C. Venancio ${ }^{a}$, M. F. Barriquello ${ }^{a}$, A. A. W. Hechenleitner ${ }^{b}$, E. A. G. Pineda ${ }^{b}$ \\ ${ }^{a}$ Embrapa - Instrumentação Agropecuária, Rua XV de Novembro, 1452, C.P. 741, \\ CEP:13.560-970, São Carlos, SP, Brazil \\ ${ }^{b}$ Departamento de Química, Universidade Estadual de Maringá, Avda. Colombo 5790, \\ CEP 87020-900 Maringá, PR, Brazil \\ *consolin@cnpdia.embrapa.br
}

\begin{abstract}
The adsorption kinetics and equilibrium of methylene blue (MB) onto reticulated formic lignin (RFL) from sugar cane bagasse was studied. The adsorption process is $p H$, temperature and ionic strength $(\mu)$ dependent and obeys the Langmuir model. Conditions for higher adsorption rate and capacity were determined. The faster adsorption (12 hours) and higher adsorption capacity (34.20 mg. $\mathrm{g}^{-1}$ ) were observed at $p H=5.8$ (acetic acid-sodium acetate aqueous buffer), $50{ }^{\circ} \mathrm{C}$ and 0.1 ionic strength. Under temperature $\left(50{ }^{\circ} \mathrm{C}\right)$ control and occasional mechanical stirring it took from 1 to 10 days to reach the equilibrium.
\end{abstract}

Keywords: methylene blue; lignin; adsorption.

\section{Introduction}

Water is polluted as a consequence of the domestic and industrial men activity. This includes varying extents and types of pollutants. It is a complex problem that sometimes is not always considered with the proper seriousness. Many scientists are putting efforts to understand these systems and to propose new methods to overcome this problem. Such methods include precipitation, flocculation, adsorption, and biodegradation processes [1]. In general, different processes must be combined to achieve the desired contaminants removal level.

Colored effluents receive special attention because they are easily detected and on the other hand, the chemical structure of such dyes varies enormously. Certain methods can work very well for the uptake of a specific group of dyes but sometimes they can be inefficient to remove other different types of dyes. Adsorption methods have received great attention because they are effective and their application processes are relatively simple. Activated carbon is the most widely used adsorbent for color removal. It has the ability to adsorb large amounts of various types of dye. Due to its relatively high cost, other lower cost materials have been also investigated as adsorbents for dye removal from aqueous media. Some of these materials are: chitin [2], Fuller's earth and fired clay [3], cellulose based polymers [4], peat [5] and wood [6]. Lignin-based materials were also investigated: post-vanillin lignin for cationic and anionic dyes [7, 8] and hydrolytic lignin modified with cationic surfactant for anionic dye adsorption [9]. The results have shown that through lignin chemical modification and/or by just varying the adsorption conditions, the use of lignin as an adsorbent for dye removal from aqueous media can be significantly 
enhanced. In some cases it showed a higher adsorption capacity than activated carbon.

In this work is presented the use of reticulated formic lignin as an adsorbent material for methylene blue removal from aqueous media. Lignin was obtained from sugar cane bagasse, an abundant agro-industrial residue in various regions of Brazil. The adsorption equilibrium and kinetic studies were carried out by varying the temperature, $\mathrm{pH}$ and ionic strength $(\mu)$.

\section{Experimental details}

\section{Formic lignin from sugar cane bagasse}

Sugar cane bagasse was obtained from a local Sugar and Alcohol Industry (USACIGA). The sample was firstly washed with excess of deionized water, dried at room temperature (25 $\left.{ }^{\circ} \mathrm{C}\right)$, and then it was grounded in a knife mill. The fraction up to 100 mesh of particle size was isolated for further studies. From the sugar cane bagasse powder $(200 \mathrm{~g})$, extractives were removed by using a soxhlet apparatus, in three stages using the following solvents $(0.5 \mathrm{~L})$ : $\mathrm{n}$ hexane (Mallinckrodt - AR), ethanol (Synth) and deionized water (this sequence), until the liquid remained uncolored in each solvent. Lignin was then extracted under reflux $\left(\sim 100^{\circ} \mathrm{C}\right)$ during three hours in the presence of formic acid (80\%) (J. T. Baker). Aqueous $1 \%(w / v)$ hydrochloric acid $(\mathrm{HCl})$ (Merk) used as catalyst and the liquid-to-solid ratio was $115 \mathrm{~mL}$ to $10 \mathrm{~g}$. The liquor obtained was concentrated in a rotatory evaporator until a viscous liquid was obtained. The lignin precipitation was obtained by adding deionized water (drop by drop) to the viscous liquid, where hemicelluloses remains dissolved. The lignin was isolated and it was then dissolved in hot formic acid followed by precipitation by adding water. The resulting lignin precipitate was filtered and the solid portion collected. The filtrate (solid portion, lignin) was then oven dried at $60^{\circ} \mathrm{C}$ during 60 minutes. The formic lignin (FL) obtained was grounded by using a ceramic mortar and pestle and it was then stored in dark glass flasks. In order to obtain an insoluble lignin sample, FL was reticulated as described below.

\section{Formic lignin reticulation}

As reticulating agent acidic formaldehyde (Synth) solution was used. $10 \mathrm{~mL}$ of $40 \%$ formaldehyde and $5 \mathrm{~mL}$ of $37 \% \mathrm{HCl}$ aqueous solution were added to $0.4 \mathrm{~g}$ of FL and the resulting mixture was maintained under reflux $\left(\sim 100^{\circ} \mathrm{C}\right)$ during $30 \mathrm{~min}$. The dispersion was then filtered and the resulting solid material was washed and vacuum (mechanical) dried at $60^{\circ} \mathrm{C}$ until the sample presents a constant weight.

\section{Solubility of lignin samples}

Aqueous sodium acetate/acetic acid buffer solutions $(p H=4.5$ and 5.8), aqueous $\mathrm{HCl}$ solution $(p H=2)$, and aqueous sodium hydroxide $(p H=8.0)$ were prepared.

$50 \mathrm{mg}$ of lignin sample was added to a round bottom volumetric flask containing $25 \mathrm{~mL}$ of aqueous sodium acetate/acetic acid $p H=4.5$ buffer solution. The solubility of lignin sample in buffer system was monitored by measuring absorption increments at $280 \mathrm{~nm}$ (HITACHI U-2000 spectrophotometer). The exact same procedure as described above was repeated except that the following aqueous systems were used: (1) aqueous sodium acetate/acetic acid $p H=5.8$ buffer solution; (2) $p H=2.0 \mathrm{HCl}$ aqueous solution; (3) $p H=8.0$ sodium hydroxide $(\mathrm{NaOH})$ aqueous solution. The lignin samples used were FL and RFL, respectively.

\section{Adsorption experiments}

Methylene blue (MB) aqueous solution (10.0 mg. $\mathrm{mL}^{-1}$ ) was prepared by using deionized water and a buffer aqueous solutions $(p H=4.5$ and 5.8). $50 \mathrm{mg}$ of RFL was added to a round bottom volumetric flask containing $25 \mathrm{~mL}$ of $\mathrm{MB}$ aqueous solution and it was then left inside a thermostatic bath during 0.5 to 10 days with occasional mechanical siring. The resulting dispersions were then centrifuged and the MB concentration of the supernatant solution was determined by absorption measurements at $662 \mathrm{~nm}$ (HITACHI U-2000 spectrophotometer). The amount of $\mathrm{MB}$ adsorbed was calculated from the difference between the MB concentration in the solutions before and after the adsorption studies.

For adsorption equilibrium studies, the RFL-MB contact time used was 10 days, at various temperatures $\left(30,40,50{ }^{\circ} \mathrm{C}\right)$. 
The ionic strength $(\mu)$ controlled experiments were carried out by adding sodium chloride $(\mathrm{NaCl})$ to deionized water to attain ionic concentration of 0.5 and 1.0. The exact amount of $\mathrm{NaCl}$ added prepare $p H$ and $\mu$ controlled aqueous solutions was calculated using the HendersonHasselbach modified equation [10]. All experiments of adsorption were performed in duplicate.

\section{Results and discussion}

The solubility of the FL and RFL samples in aqueous solutions was quantified by measuring the UV absorption intensity at $280 \mathrm{~nm}$. It was observed that RFL presented the lowest solubility in all studied systems, i.e. aqueous buffer solution $(p H=4.5$ and 5.8, maximum of absorption intensity $=0.06$ a.u.) and $\mathrm{HCl}$ and $\mathrm{NaOH}$ aqueous solutions $(p H=2.0$ and 8.0, maximum of absorption intensity $=0.11$ a.u.). The FL presented relatively high solubility in all systems studied, where the maximum of absorption intensity at $280 \mathrm{~nm}$ was higher than 1.6 a.u.. Therefore, RFL was used for the MB adsorption studies.

Figure 1 shows the dye concentration decay for $\mathrm{MB}$ initial concentration of 10.0 mg.mL $\mathrm{m}^{-1}$ in the presence of RFL at $30^{\circ} \mathrm{C}$. The rate of $\mathrm{MB}$ uptake from buffered aqueous solutions at $p H=5.8$ and 4.5, respectively, is much faster than from the unbuffered aqueous solution at $p H$ $=5.9$. When the MB (10.0 mg.mL $\left.\mathrm{mL}^{-1}\right)$ was kept in the presence of RFL during five days in a $p H=$ 5.8 buffered aqueous solution almost all $\mathrm{MB}$

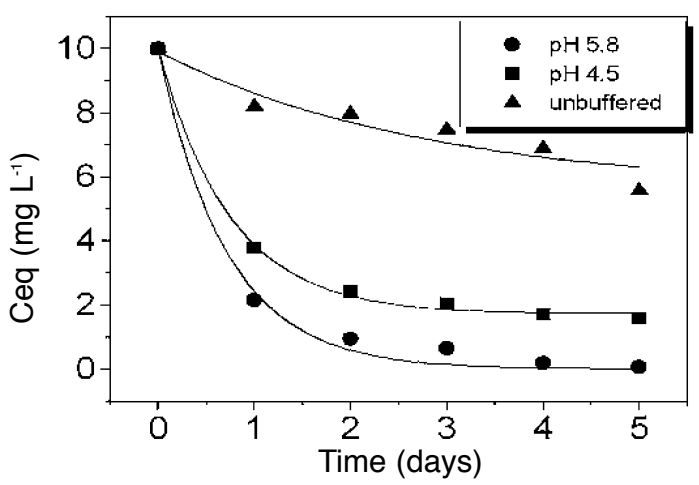

Figure 1. MB uptake by RFL in different aqueous media at $30^{\circ} \mathrm{C}$. was removed from the liquid phase. These results suggest that the $\mu$ plays an important role in the adsorption process. The $\mu$ of the buffered aqueous solutions $(p H=5.8, p H=4.5)$ is higher than of the unbuffered aqueous solutions $(p H=5.9)$.

In order to analyze the temperature influence in this MB adsorption process, adsorption experiments were carried out in the three different aqueous solutions (buffered aqueous solutions $p H=5.8, p H$ $=4.5$ and unbuffered aqueous solutions $p H=5.9$ ). The temperatures studied were: 40,50 and $60^{\circ} \mathrm{C}$. The results are summarized in Figs. 2-4. In two different systems, i.e. unbuffered $(p H=5.9)$ and buffered $(p H=4.5)$, the MB adsorption presented a maximum in the temperature range of $30-60^{\circ} \mathrm{C}$, namely at $40{ }^{\circ} \mathrm{C}$ and $50{ }^{\circ} \mathrm{C}$, respectively. In the $p H$ $=5.8$ buffered aqueous solution, $\mathrm{MB}$ is completely removed from the liquid phase at $30^{\circ} \mathrm{C}$ and at $50^{\circ} \mathrm{C}$. At $60^{\circ} \mathrm{C}$ some of the adsorbed $\mathrm{MB}$ is desorbed from the RFL surface. The minimum time interval required to reach the adsorption equilibrium, with complete dye removal, was approximately 12 hours (at $p H=5.8$ and $50^{\circ} \mathrm{C}$ ). With the unbuffered aqueous solution, the complete dye removal was not obtained and the minimum time interval required to reach the adsorption equilibrium was approximately 2 days (at $p H=5.8$ and $50^{\circ} \mathrm{C}$ ).

The three step model proposed by McKay and McConvey [11] for basic and acidic dyes adsorption on wood was used to analyze the adsorption data from this work. This model calculates the change in adsorbate concentration $\left(C_{t}\right)$ as a function of the time of adsorption $(t)$ by the equation described below:

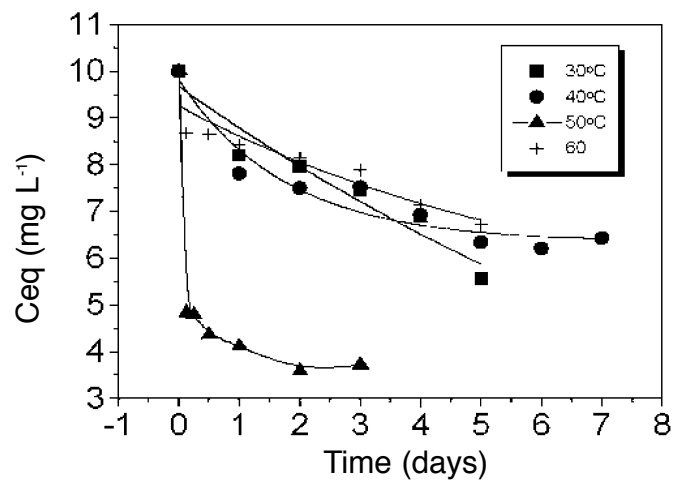

Figure 2. Temperature influence in MB adsorption onto RFL from unbuffered solution at $\mathrm{pH}=5.9$. 


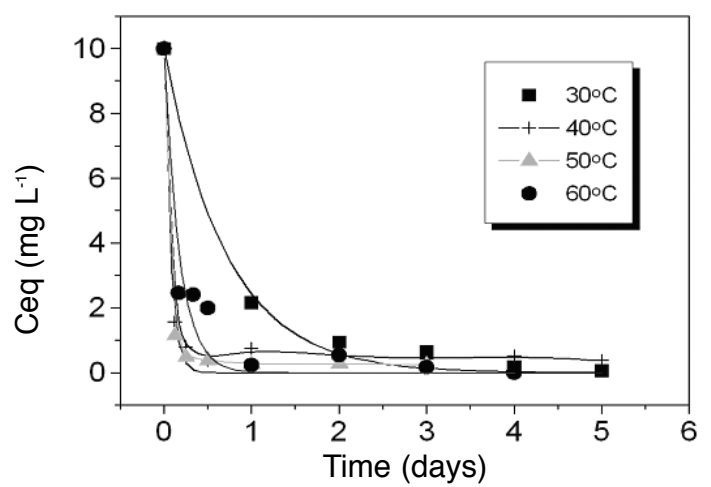

Figure 3. Temperature influence in $\mathrm{MB}$ adsorption onto RFL from buffered solution at $\mathrm{pH}=5.8$.

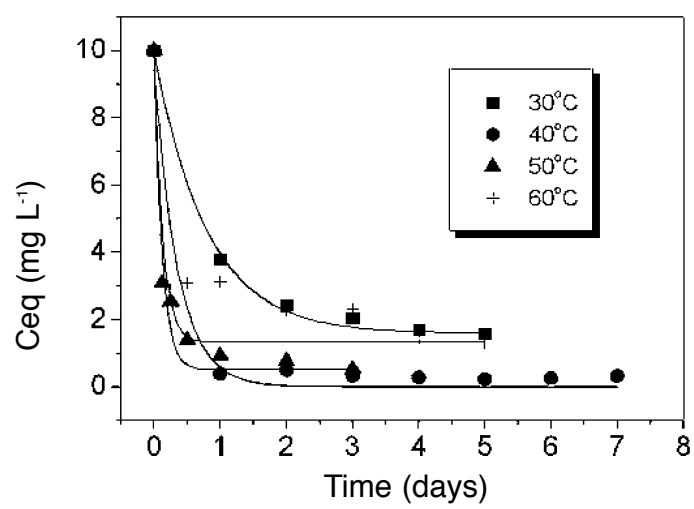

Figure 4. Temperature influence in MB adsorption onto RFL from buffered solution at $\mathrm{pH}=4.5$.

$$
\frac{d C_{t}}{d t}=\beta S\left(C_{t}-C_{S}\right) \text { and } C_{t}=C_{0} \text { at } t=0
$$

where $C_{S}$ is the adsorbate concentration in the liquid phase near the outer surface of the adsorbent particle $\left(\mathrm{mg} \cdot \mathrm{dm}^{-3}\right), \beta$ is the external mass transfer coefficient $\left(\mathrm{cm} . \mathrm{s}^{-1}\right), S$ is the outer surface of the adsorbent particles per volume unit of particle free slurry $\left(\mathrm{cm}^{-1}\right)$.

The $\beta S$ product was determined from the slope at $t \rightarrow 0$ of the $C_{t} / C_{0}$ versus $t$ plot. The results are presented in Table 1 . A high increment in $\beta S$ is observed when the temperature is increased from 30 to $40^{\circ} \mathrm{C}$ in the buffered aqueous solutions, and from 40 to $50^{\circ} \mathrm{C}$ in the unbuffered aqueous solution. On the other hand, a decrease in $\beta S$ is observed when the temperature increases from 50 to $60^{\circ} \mathrm{C}$ in the three systems described above. The $\beta S$ values calculated from experiments carried out at the same temperature for the three systems describe above increases as follows: unbuffered solution $(p H=5.9)$ $<$ buffered solution $(p H=4.5)<$ buffered solution $(p H=5.8)$. It can be observed that the adsorption kinetic depends on all three parameters, temperature, $p H$ and $\mu$. The effect of the temperature on the MB adsorption behavior on RFL is probably related to an increase of the adsorption rate with the increase of the temperature up to a limit value (50 $\left.{ }^{\circ} \mathrm{C}\right)$. This increase in the MB adsorption rate is due to the increase of the MB diffusion coefficient. At relatively high temperatures, i.e $60{ }^{\circ} \mathrm{C}$, the dessorption process is favored and thus the amount of adsorbed $\mathrm{MB}$ decreases. The effect of the $\mathrm{pH}$ on the MB adsorption process may be related to the increase of the ionization degree of the carboxylic groups present in the lignin structure when the $p H$ is increased. This increase in the ionization degree of the carboxylic groups might enhance the interaction process between the adsorbate (MB), a cationic dye and the adsorbent (RFL), which results in a driving force for adsorbate diffusion in the region near the surface of the lignin particles. The $\mu$ influence is evident when data from buffered and unbuffered aqueous solutions with $p H=5.8$ and 5.9 , respectively, are compared. $\beta S$ values calculated from $p H=5.8$ buffered aqueous solutions are much higher than $\beta S$ values calculated from $p H=$ 5.9 unbuffered aqueous solution. Therefore, it indicates that the $\mu$ of the buffer system play an important role in the adsorption process.

Adsorption equilibrium experiments were also done. A MB adsorption time of 10 days was used. The influence of the aqueous medium, i.e. $p H$ and $\mu$, and temperature was also analyzed. The Langmuir model fits well to all isotherms obtained in this study, as it can be seen from in Fig. 5. Figure 5 shows an increase on the adsorbed adsorbate concentration $(q)$ with the increase of the adsorbate concentration in the liquid phase at the equilibrium $\left(\mathrm{C}_{\mathrm{eq}}\right)$ up to a $\mathrm{C}_{\mathrm{eq}}$ limit value, after which no further change in q values is observed. The $\mathrm{C}_{\mathrm{eq}}$ limit value is equal to $10 \mathrm{mmol} \mathrm{L}^{-1}$ at $p H=5.8$ (buffer system). In other hand, the unbuffered system $(p H=5.9)$ did not reach a $\mathrm{C}_{\mathrm{eq}}$ limit value. The Langmuir isotherm can be written as described below:

$$
q=\frac{q_{m} K_{L} C_{e q}}{1+K_{L} C_{e q}}
$$


Table 1. $\beta S$ data for the adsorption of MB on RFL obtained from sugar cane bagasse.

\begin{tabular}{cccc}
\hline & & \multicolumn{2}{c}{$\beta \mathrm{SS}_{\left(\text {day }^{-1}\right)}$} \\
\hline $\mathrm{T}^{\circ} \mathrm{C}$ & $\mathrm{pH}=5.9$ & $\mathrm{pH}=5.8$ & $\mathrm{pH}=4.5$ \\
& Unbuffered & Buffered & Buffered \\
\hline 30 & 0.18 & 0.78 & 0.62 \\
40 & 0.22 & 4.54 & 4.78 \\
50 & 4.12 & 7.08 & 5.54 \\
60 & 1.06 & 6.75 & 4.93 \\
\hline
\end{tabular}

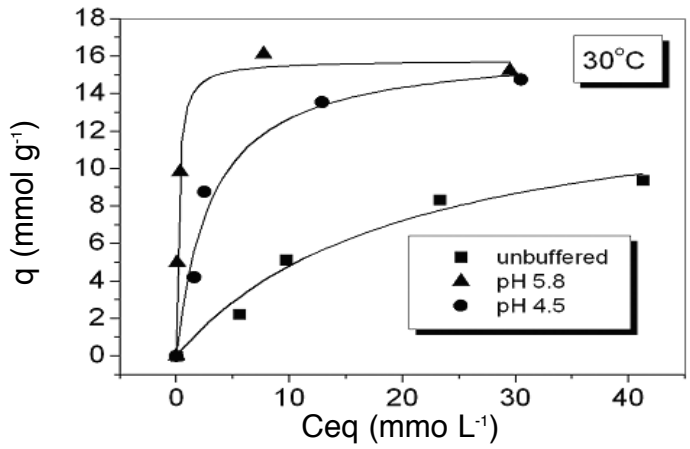

Figure 5. Adsorption isotherms of MB on RFL in the presence of three different aqueous solutions, as indicated in the figure. Solid lines are theoretical Langmuir isotherms and symbols are experimental data. where $C_{e q}$ is the adsorbate concentration in the liquid phase at equilibrium, $q$ is the adsorbed adsorbate concentration at equilibrium, $q_{m}$ is the adsorbent capacity, $K_{L}$ is a measure of the adsorption intensity (Langmuir constant).

The $q_{m}$ and $K_{L}$ data for all adsorption equilibrium experiments were obtained from the fit of the experimental data to the Langmuir equation. These results are shown in Tables 2 and 3.

The data from Tables 2 and 3 shows that the adsorption rate behavior do not fit to the adsorption capacity behavior. Data for unbuffered aqueous solution at $30^{\circ} \mathrm{C}$ are the most particular ones, where the slower process results to an adsorption capacity similar to those obtained from buffered aqueous medium at the same temperature. At the two other temperatures $\left(40\right.$ and $50{ }^{\circ} \mathrm{C}$ ) the adsorption capacity of the RFL in buffered solution is more than three times higher than the corresponding adsorption capacity of the unbuffered aqueous solution. On the other hand, for the unbuffered aqueous solution the higher adsorption capacity occurs at the lower temperature $\left(30^{\circ} \mathrm{C}\right)$, and for the buffered aqueous solutions the higher adsorption capacity occurs at the higher temperature $\left(50^{\circ} \mathrm{C}\right)$. There is no definite tendency of $K_{L}$ data when the temperature is changed but at a constant temperature it increases in the following order: unbuffered aqueous solution $(\mathrm{pH}=$

Table 2. Effect of the adsorption system conditions ( $\mathrm{pH}, \mu$, temperature) on the Langmuir parameters for the adsorption of MB onto RFL.

\begin{tabular}{ccccccc}
\hline & \multicolumn{2}{c}{ Unbuffered, $\mathrm{pH}=5.9$} & \multicolumn{2}{c}{ Buffered, $\mathrm{pH}=5.8$} & \multicolumn{2}{c}{ Buffered, $\mathrm{pH}=4.5$} \\
\hline $\mathrm{T}^{\circ} \mathrm{C}$ & $\mathrm{q}_{\mathrm{m}}\left(\mathrm{mg} \mathrm{g}^{-1}\right)$ & $\mathrm{K}_{\mathrm{L}}\left(\mathrm{L} \mathrm{mg}^{-1}\right)$ & $\mathrm{q}_{\mathrm{m}}\left(\mathrm{mg} \mathrm{g}^{-1}\right)$ & $\mathrm{K}_{\mathrm{L}}\left(\mathrm{L} \mathrm{mg}^{-1}\right)$ & $\mathrm{q}_{\mathrm{m}}\left(\mathrm{mg} \mathrm{g}^{-1}\right)$ & $\mathrm{K}_{\mathrm{L}}\left(\mathrm{L} \mathrm{mg}^{-1}\right)$ \\
\hline 30 & 14.57 & 0.049 & 15.72 & 5.70 & 16.50 & 0.33 \\
40 & 4.11 & 0.22 & 20.17 & 1.43 & 14.95 & 0.51 \\
50 & 5.64 & 0.35 & 34.20 & 0.71 & 20.06 & 0.51 \\
\hline
\end{tabular}

Table 3. Adsorption capacity according to Langmuir model, for MB adsorption onto RFL, in relation to $\mathrm{pH}$, temperature and $\mu$.

\begin{tabular}{lcccccc}
\hline & \multicolumn{5}{c}{$\mathrm{q}_{\mathrm{m}}\left(\mathrm{mg} \mathrm{g}^{-1}\right)$} \\
\hline $\mathrm{T}^{\circ} \mathrm{C}$ & \multicolumn{3}{c}{$\mathrm{pH}=4.5$} & \multicolumn{4}{c}{$\mathrm{pH}=5.8$} \\
\hline & $\mu=0.1$ & $\mu=0.5$ & $\mu=1.0$ & $\mu=0.1$ & $\mu=0.5$ & $\mu=1.0$ \\
30 & 16.50 & 6.21 & 3.55 & 15.72 & 6.82 & 3.96 \\
50 & 20.06 & 17.62 & 21.82 & 34.20 & 31.55 & 31.71 \\
\hline
\end{tabular}


$5.9)<$ buffered aqueous solution $(p H=4.5)<$ buffered aqueous solution ( $p H=5.8$ ).

In Table 3 it can be observed that, at $30^{\circ} \mathrm{C}$, the $0.1 \mu$ gives the higher adsorption capacity. At $50^{\circ} \mathrm{C}$ this parameter has a little effect on the adsorption capacity, which might indicates that in this condition the temperature effect is more important. Comparing the results from unbuffered aqueous solution $(p H=5.9)$ presented in Table $2\left(q_{m}=5.64\right.$ mg. $\mathrm{g}^{-1}$ at $50^{\circ} \mathrm{C}$ ) with the results from buffered aqueous solution $(p H=5.8)$ presented in Table 3 $\left(q_{m}=34.20 \mathrm{mg} \cdot \mathrm{g}^{-1}\right.$ at $\left.50^{\circ} \mathrm{C}\right)$ it can be concluded that $q_{m}$ reach's a maximum at an $\mu$ of approximately 0.1 . The effect of $\mu$ lower than 0.1 in buffered aqueous solution could not be analyzed due to acetic acid/sodium acetate minimum concentrations that are required to prepare the buffer systems.

The Scatchard equation that is described below

$$
\frac{\theta}{C_{e q}}=K_{L}(1-\theta) \quad \text { where } \quad \theta=\frac{q}{q_{m}}
$$

is often used to study binding to macromolecules [12]. If the adsorption model considered is valid, a plot of $q / C_{e q}$ versus q will be linear, the intercept is $K_{L} q_{m}$, and the slope is equal to $-K_{L}$. When the Scatchard plot does not give a unique straight line, this indicates that the binding sites are not identical or are not independent. Figure 6 shows the Scatchard plots for the MB adsorption onto RFL at $30^{\circ} \mathrm{C}$. Similar plots were obtained at $40^{\circ} \mathrm{C}$ and

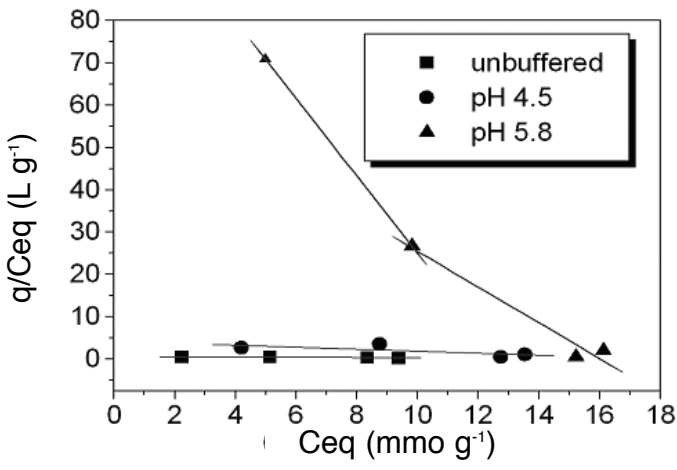

Figure 6. Scatchard plots for the adsorption equilibrium of $\mathrm{MB}$ onto $\mathrm{RFL}$ at $30^{\circ} \mathrm{C}$.

$50^{\circ} \mathrm{C}$. Comparing the results from Fig. 6 with the results from Fig. 5, it can be seen that the adsorption data obtained at $p H=5.8$, which shows a deviation from the linearity in Fig. 6, corresponds to the isotherm that has achieved the saturation. This behavior is related to the fact that, at higher $\theta$, interactions between binding sites become more likely.

The Scatchard's plots for the adsorption systems under study in the conditions mentioned in Table 2 were analyzed. Table 4 shows the Scatchard parameters, $K_{L}$ and $q_{m}$. They coincide with the corresponding Langmuir parameters only in the cases in which two straight lines are obtained, when they are computed from the lower one. In the other cases the Langmuir parameters are always higher than the corresponding Scatchard parameters, indicating

Table 4. Scatchard's parameters for the adsorption of MB onto LFB.

\begin{tabular}{lccc}
\hline & Temperature $\left({ }^{\circ} \mathrm{C}\right)$ & $\mathrm{K}_{\mathrm{L}}$ & $\mathrm{Q}_{\mathrm{m}}$ \\
\hline Unbuffered, pH 5.9 & 30 & 0.02 & 21.96 \\
Buffered, pH 4.5 & 30 & 0.23 & 18.68 \\
Buffered, pH 5.8 (upper) & 30 & 11.03 & 12.23 \\
$\quad$ (lower) & & 4.76 & 15.43 \\
Unbuffered, pH 5.9 & 40 & 0.04 & 8.80 \\
Buffered, pH 4.5 & 40 & 1.48 & 13.09 \\
Buffered, pH 5.8 (upper) & 40 & 78.6 & 9.71 \\
$\quad$ (lower) & & 1.48 & 20.01 \\
Unbuffered, pH 5.9 & 50 & 0.35 & 5.71 \\
Buffered, pH 4.5 & 50 & 0.59 & 19.54 \\
Buffered, pH 5.8 (upper) & 50 & 0.64 & 27.94 \\
$\quad$ (lower) & & 0.75 & 34.12 \\
\hline
\end{tabular}


Table 5. Factors and levels of a factorial design 23 for the adsorption of MB onto RFL.

\begin{tabular}{lcc}
\hline Simbol - Variable & Data (level) & Data (level) \\
\hline A: $\mu$ & $0.5(-)$ & $1.0(+)$ \\
B: $\mathrm{pH}$ & $4.5(-)$ & $5.8(+)$ \\
C: Temperature $\left({ }^{\circ} \mathrm{C}\right)$ & $30(-)$ & $50(+)$ \\
\hline
\end{tabular}

Table 6. Results of the factorial design for the adsorption of MB onto LFR.

\begin{tabular}{|c|c|c|c|c|}
\hline Experiment & A & B & $\mathrm{C}$ & $\mathrm{q}_{\mathrm{m}}\left(\mathrm{mg} \mathrm{g}^{-1}\right)$ \\
\hline 1 & - & - & - & 6.21 \\
\hline 2 & + & - & - & 3.55 \\
\hline 3 & - & + & - & 6.82 \\
\hline 4 & + & + & - & 3.96 \\
\hline 5 & - & - & + & 17.62 \\
\hline 6 & + & - & + & 21.82 \\
\hline 7 & - & + & + & 31.55 \\
\hline 8 & + & + & + & 31.71 \\
\hline \multicolumn{2}{|c|}{ Variable } & & \multicolumn{2}{|c|}{ Answer } \\
\hline & I & & \multicolumn{2}{|c|}{14.75} \\
\hline & A & & \multicolumn{2}{|c|}{-0.50} \\
\hline & B & & \multicolumn{2}{|c|}{6.00} \\
\hline & $\mathrm{AB}$ & & \multicolumn{2}{|c|}{-1.00} \\
\hline & $\mathrm{C}$ & & \multicolumn{2}{|c|}{20.00} \\
\hline & $\mathrm{AC}$ & & \multicolumn{2}{|c|}{2.50} \\
\hline & $\mathrm{BC}$ & & \multicolumn{2}{|c|}{6.00} \\
\hline & $\mathrm{ABC}$ & & \multicolumn{2}{|c|}{-1.00} \\
\hline
\end{tabular}

that in the first case the final portion of the isotherm is more important and the Scatchard treatment is more sensible to the initial portion of that curve. The non linear Scatchard plots cannot be attributed to higher adsorption capacity or adsorption process rate as can be seen comparing with data in Tables 1 and 2. There are $\beta S$ and $K_{L}$ data of the unbuffered $(p H=5.9)$ and the buffered $(p H=4.5)$ aqueous systems in the same interval as the data of buffered aqueous system $(p H=5.8)$, which show a linear behavior in the Scatchard plot.

To $q_{m}$ data, a full $2^{3}$ factorial design (three factors, each at two levels) was applied. The standard experimental matrix for the factorial design and the results of $q_{m}$ are shown in Table 5. A statistical analysis was performed on these $q_{m}$ results, and the main effects and interaction effects for the dif- ferent variable combinations were calculated. The results (Table 6) show that temperature is the most important factor in the MB adsorption. Increasing the $\mu$ (A), the adsorption decreases, even when $p H$ (B) and temperature (C) increases, as showed by the results of interactions $\mathrm{AB}, \mathrm{AC}$ and $\mathrm{ABC}$.

\section{Conclusions}

Formic lignin from sugar cane bagasse can be reticulated through a simple reaction with formaldehyde to obtain a product with low solubility in aqueous media. This material was able to be used as an adsorbent for MB removal from aqueous media. The adsorption process showed $p H$, temperature and ionic strength dependence and obeyed the 
Langmuir model. The general tendencies observed with the adsorption capacity are:

- It decreases when the $\mu$ increases in the range of 0.1 to 1.0 ,

- It increases when the temperature increases in the range of 30 to $50^{\circ} \mathrm{C}$,

- It increases when the $p H$ increases in the range from 4.5 to 5.8 , in buffered aqueous solutions.

- The faster adsorption and higher capacity were observed at $50^{\circ} \mathrm{C}, \mathrm{pH}=5.8$ and 0.1 of $\mu$, for which interactions between binding sites were detected through Scatchard analysis.

- $\quad \mu$ is a very important variable especially at $30^{\circ} \mathrm{C}$ in all $\mathrm{pH}$ values studied. Increasing $I, q_{m}$ decreases dramatically at this temperature.

- The $q_{m}$ values of methylene blue adsorbed onto reticulated lignin from sugar cane bagasse can be described by the equation

- $\quad q_{m}=14.75-0.5(I)+6.00(p H)-1.00(\mathrm{I})(p H)+$ $20.00(t)+2.50(I)(t)+6.00(p H)(t)-1.00(I)$ $(p H)(t)$
- when the experiments are carried out according to the factorial design described in Table 5.

- The adsorption of MB onto RFL is exothermic process when it is carried out at $p H=5.8$

- It is possible to prepare adsorbents at low cost from lignin that can adsorb methylene blue, since sugar cane bagasse is relatively cheap material and it can be found in any region of in Brazil.

\section{Acknowledgements}

NCF acknowledge FAPESP (proc. No 06/58872-0), and Embrapa - Instrumentação Agropecuária. EAGP and AAWH acknowledge DQI - UEM and grants from CNPq proc.500.527/95-0 and 300.694/90-3.

Received 11 September 2007

Accepted 22 November 2007

N. Consolin Filho, E. C. Venancio, M. F. Barriquello, A. A. W. Hechenleitner, E. A. G. Pineda, Adsorção de azul de metileno em lignina modificada obtida do bagaço de cana de açúcar.

Resumo: Estudou-se neste trabalho, a cinética de adsorção e o equilíbrio de adsorção do azul de metileno (AM) em lignina fórmica reticulada (LFR) obtida do bagaço de cana de açúcar. O processo de adsorção é dependente do $p H$, temperatura e força iônica $(\mu)$ e obedece ao modelo de Langmuir. Algumas condições como a alta capacidade e velocidade de adsorção foram determinadas. Observouse rápida adsorção (12 horas) e alta capacidade de adsorção (34,20 mg.g-1) em pH= 5,8 (tampão acetato de sódio-ácido acético), $50^{\circ} \mathrm{C}$ e 0,1 de força iônica. Para alcançar o equilíbrio de adsorção, o sistema foi termostatizado com tempos de 1 a 10 dias, com agitação ocasional.

Palavras-chave: azul de metileno; lignina; adsorção.

\section{References}

[1] M. L. Richardson, JSDC 99 (1983) 198-200.

[2] G. McKay, H. S. Blair, J. R. Gardner, J. Appl. Polym. Sci. 29 (1984) 1499-1514.

[3] G. McKay, M. S. Otterburn, J. A. Aga, Water, Air and Soil Pollution 24 (1985) 307-322.

[4] M. C. Hwang, K. M. Chen, J. Appl. Polym. Sci. 48 (1993) 48, 299-311.

[5] S. J. Allen, G. K. McKay,Y. J. H. Khader, J. Colloid and Interface Sci. 126 (1988) 517-524.

[6] H. M. Asfour, O. A. Fadali, M. M. M. S. El-Geundi, J. Chem. Technol. Biotechnol. 35A (1) (1985) 21-27.
[7] J. Lebek, W. Wardas, Cellulose Chem. Technol. 30 (1996) 213-221.

[8] W. Wardas, J. Lebek, Cellulose Chem. Technol. 28(3) (1994) 255-263.

[9] A. F. Nikiforov, O. V. Lokai, V. V. Pushkarev, Khim. Tekhnol. Vody. 9(1) (1987) 73-76.

[10] M. A. Hashim, K. H. Chu, P. S. Tsan, J. Chem. Tech. Biotechnol. 62 (1995) 253-260.

[11] G. McKay, I. F. McConvey, J. Chem. Tech. Biotechnol. 31 (1981) 401-408.

[12] JR. I. Tinoco, K. Sauer, J. C. Wang, Physical Chemistry - Principles and Applications in Biological Sciences, $3^{\text {rd }}$. Ed., Prentice - Hall Inc., New Jersey, 1995, chap. 5. 